discipline, is it going to provide the fresh kind of expertise needed to give advice on environmental policy? I confess to doubts on this matter, and for a simple reason. It is that the experts in making political or administrative decisions are politicians and administrators; they are accountable to the public, and it is arguable whether the process of integration should not be left to them. There is a risk that the boundary between what is rational and objective and disinterested information, on the one hand, and its use for making valuejudgements, on the other hand, would become blurred if environmental scientists were to take too much responsibility from politicians. Maybe the fresh kind of expert should not be a scientist.

Caldwell's book is a lucid and important contribution to this question. It is also a timely vindication of the National Environmental Policy Act: a sane assessment of its value, written with great authority, for Caldwell took part in the preparation of the Act. (He records how an early draft of Section 101 of the Act gave Americans the "right to a healthful environment". But Congress shrunk from such a commitment, and amended it to "should enjoy a healthful environment"!) $\mathrm{He}$ is resentful - as well he might be about the casual way the present Administration regards environmental issues. But he has faith that the American people, whose ardour for a Green America was so heartening a few years ago, will recover this ardour, shed, perhaps, of some of its weakening extravagances. And, with a change of scenery and a different backcloth, what Caldwell writes about America could be written about Europe.

Lord Ashby is a Fellow of Clare College, Cambridge. He was Chairman of the Royal Commission on Environmental Pollution from 1970 to 1973.

\section{Change of parasites}

\section{Kenneth S. Warren}

\author{
Modern Parasitology: A Textbook of \\ Parasitology.
}

Edited by F.E.G. Cox.

Blackwell Scientific/Blackwell Mosby: 1982. Pp.346. Pbk £12.50, \$23.95.

\begin{abstract}
"PARASITOlOGY" is a relatively new discipline! While all infectious agents (viruses, bacteria, fungi, protozoa, helminths) are parasites, it was not until the period 1914-1940 that study of the protozoa and helminths emerged as a separate subject. The basic distinction was that protozoa and helminths were animal parasites; at one time Nuttal even called viruses and bacteria "vegetable parasites". Yet despite the comparatively recent establishment of "parasitology", it is a field which is sorely in need of modernization.

It is gratifying, therefore, to report that Modern Parasitology fulfils the call of Paul Weinstein at a conference in 1980 on "The Current Status and Future of Parasitology" (published by the Josiah Macy $\mathrm{J}$. Foundation in 1981) for a new type of parasitology textbook organized by "process" rather than by taxonomy, and taking cognizance of the revolutionary changes in
\end{abstract}

\section{Medical entomology}

The third edition of James R. Busvine's Insects \& Hygiene: The Biology and Control of Insect Pests of Medical and Domestic Importance has been issued in paperback by Chapman \& Hall. Price is $£ 12.50$.

\section{Vertebrate endocrinology}

Cambridge University Press have recently published a second, fully up-dated editon of Comparative Vertebrate Endocrinology by P.J. Bentley. The first edition was reviewed in Nature 260, 215; 1976. Prices are £32.50, \$49.50 in hardback and $£ 12.50, \$ 19.95$ in paperback. biology in the past few decades. This book, however, is not the major new textbook that Weinstein envisaged. It is precisely what the editor says it is, a book intended mainly for undergraduates to be used in conjunction with standard textbooks. As such it is an important addition to the literature of parasitology.

While the book contains good summaries of combined protozoan and helminth biochemistry, physiology (the rationale for a separate chapter on nutrition is not clear) and immunology, the chapter on epidemiology is particularly worthy of note. This is the new and exciting melding of epidemiology and mathematical ecology pioneered by Roy Anderson and Robert May. Anderson divides the parasites into micro- (viruses, bacteria, protozoa) and macro- (helminths, arthropods), and emphasizes the enormous epidemiological differences between these two groups of organisms.

Perhaps Weinstein's hoped for "major new textbook" will include all of the parasites, animal and vegetable, micro and macro. If the will and the space are not available, however, it might be better if the very different protozoa and helminths were treated separately as subdisciplines (in a manner analogous to viruses and bacteria) interrelated by the biology of parasitism. In the meantime, Modern Parasitology lives up to its title and points to the new directions in this field so important to the wellbeing of humans and domestic animals.

The book is attractively produced and easy to read. It is also remarkably durable, being reviewed on safari in East Africa and emerging from the ordeal in near pristine condition.

Kenneth S. Warren is Director of Health Sciences at the Rockefeller Foundation, New York. He is a co-editor of Parasitology: A Global Perspective, to be published by SpringerVerlag later this year.

\section{Looking for life}

\section{A.G. Cairns-Smith}

Cosmochemistry and the Origin of Life. Edited by Cyril Ponnamperuma.

Reidel: 1983. Pp. 385. Dfl.145, \$63.

HANDS up those who had known all along that the clouds of Venus would be of concentrated sulphuric acid; or that the surface of Mars would be devoid of organic molecules; or that the satellites of Jupiter would be so individual; or . . . . Every space probe to the planets has provided surprises, usually several of them. Expect to be surprised, then, by the chemistry of distant parts of the Universe and remote periods of the Earth's history.

We have here a series of review essays, stemming from a NATO Advanced Study meeting held in 1981 (reported in Nature 292,$669 ; 1981$ ). They are written by a wellchosen group of authors and held together by a faith in "chemical evolution", namely that the Universe progresses in some sense towards life via "the atoms of life", "the molecules of life" etc. So we start with element synthesis and go on to organic molecules in deep space, to the search for life or its precursors in the Solar System and then to Earth, to the evolution of its atmosphere and hydrosphere, and to its ancient sediments.

In the event the surprises outnumber the confirmations of faith. "Chemical evolution" starts well by preferring "the atoms of life" in stellar nuclear synthesis. But when it comes to making organic molecules (most of which in our Universe are out there, between the stars, in gas clouds, on dust grains and in comets) then you have to be optimistic to see any great preference for "the molecules of life". The relevance, it seems, is more oblique: some of the interstellar organic materials are bound to add their atoms to newly forming planets in immense varieties of proportions and circumstances to provide possibilities for evolving organisms made from carbon, nitrogen and so on, in an immense variety of worlds.

Meteorites and lunar samples tell of conditions in the early Solar System, and it seems almost too good to be true that we also have "time probes" relating to conditions on the early Earth itself - in the form of well-dated rocks, the oldest from about 3,800 million years ago. That is a long way back when you consider that the Earth only started forming some $4,500 \mathrm{Myr}$ ago and may well have been only settled enough for life by about 4,000 Myr. There is quite good fossil evidence for photosynthetic organisms 3,500 Myr ago. Although still a matter of debate ${ }^{13} \mathrm{C}$ studies on the 3,800-Myr-old rocks are consistent, at least, with a plant life already well established then. More surely, these most ancient rocks tell of an Earth already settled into cycles of weathering and sedi- 